\title{
Relationship Between Information Literacy Skills and Research Productivity of Researchers in Nigeria, and the Mediating Role of Socio-Economic Factors
}

\author{
Simisaye Ahmed Olakunle \\ Department of Library \& Information Science, \\ Tai Solarin University of Education, Ijagun, Ogun-State, Nigeria \\ simisayeao@tasued.edu.ng \\ Popoola Sunday Olanrewaju \\ Department of Library, Archival \& Information Studies, \\ University of Ibadan, Nigeria \\ drpopoola@gmail.com
}

\begin{abstract}
Objective. This study investigated the influence of information literacy skills on the research productivity of academic staff in Nigeria, with the mediating role of socioeconomic factors.

Methods. Out of a total of 782 academic staff in research institutes in South West Nigeria, 610 responded to a questionnaire survey. Descriptive, correlation analysis and hierarchical regression analysis were used to analyze the data.

Results. A relationship was found between information literacy skills and research productivity $(\mathrm{r}=0.56, \mathrm{p}<0.05)$. Socio-economic factors (monthly salary, academic status, age, highest educational qualification, work experience and employment nature) have mediating effects on the relationship between information literacy skills and research productivity. Together, they accounted for $47 \%$ of the variance in the research productivity of the respondents.

Recommendation. Management of the research institutes should put more effort in increasing the level of information literacy skills, taking into consideration the socioeconomic factors identified.
\end{abstract}

\section{INTRODUCTION}

Having realized that research is the bedrock of development, countries commit tremendous efforts and funds to research in the bid to develop economically, socially and technologically. One of the efforts promoting research is the establishment of research institutes by countries specifically for galvanizing growth and development. Nigeria is one of these countries.

The academic staff in the research institutes are expected to carry out research and get them published in reputable outlets. Throughout the world, career and professional development of academic staff members are determined by their publications in various forms. By virtue of their work and positions, apart from educational qualifications and cognate experience, they are required to get appointments and promotions on evidence of 
satisfying research publications in reputable journals, conference proceedings and seminar papers among others.

Research productivity has been defined as the relationship between the input and output generated by a system. It may also include the term efficiency and more importantly, effectiveness, which measures the total output or results of performance (Turnage, 1990). Print and Hattie (1997) defined research productivity as the totality of research performed by academics in universities and related contents within a given time period (p. 454). Williams (2003) noted that research productivity could be defined in terms of researchers' products and efforts. Most studies measure productivity by calculating a composite indicator derived by summing the number of finished research reports, published reports and utilized research reports. In this study, research productivity is operationalized as the total number of journal articles, textbooks, monographs, conference proceedings, technical reports, chapters in books, theses, dissertations, scientific peer reviews, co-authored textbooks, occasional papers and patents produced by the academic staff in the Nigerian research institutes within the survey period of 2013 to 2018 .

Information literacy skills (ILS) is an important concept for this study. Information literacy has been viewed in different ways. According to the American Library Association's Presidential Committee on Information Literacy report released on 10 Jan 1989, ILS is a set of abilities that enable individuals to "recognize when information is needed and have the ability to locate, evaluate and use effectively the needed information" (ALA, 1989).

ILS is conceptualized in this study as sets of skills that encompass the ability of the academic staff in Nigerian research institutes to know the need for information, identify, locate, evaluate, organize and effectively create, use and communicate information ethically to address issues or problem relating to research activities leading to research publications. ILS, as conceptualized is represented and explained in the conceptual model of this study.

In the electronic information world of today, ILS possessed by an academic staff are expected to enhance his or her research productivity. Research is a general term which covers all kinds of studies designed to find responses to worthwhile questions by means of systematic and scientific approaches (Wadesango, 2014). Mason (2011) defined research as the systematic quest for knowledge. Research provides good platform for lecturers to become accomplished scholars. Research and its productivity depends to a large extent on the amount and quality of information accessed and utilized, which in turn is determined by the level of ILS of the academic staff (Okiki, 2013; Okiki \& Mabawonku, 2013; Barjak, 2006; Madu \& Dike, 2012).

Socio-economic factors as shown in the concept model of this study, cover marital status, age, family size, academic qualification, monthly salary, gender, rank/academic status employment status and work experience. There is abundant literature which indicates that socio-economic factors explain individual and organizational behavior to a large extent (Fehr \& Schmidt, 2000), and determine to some extent the workplace behavior and achievement of individuals. These factors influence the personalities of individuals, and the way they think and act in accomplishing individual and organizational goals.

Various studies have shown that socio-economic factors influence research productivity of academic staff members and researchers (Dakik, Kaidbey \& Sabra, 2006; Bland, Center, Finstad, Risbey \& Staples, 2005; Wager, 2009; Bozeman \& Corley, 2004, Pau et al., 2017).

This study aimed to determine the mediating effects of socio-economic factors on the relationship between ILS and research productivity of the academic staff in the research institutes of South West Nigeria. 


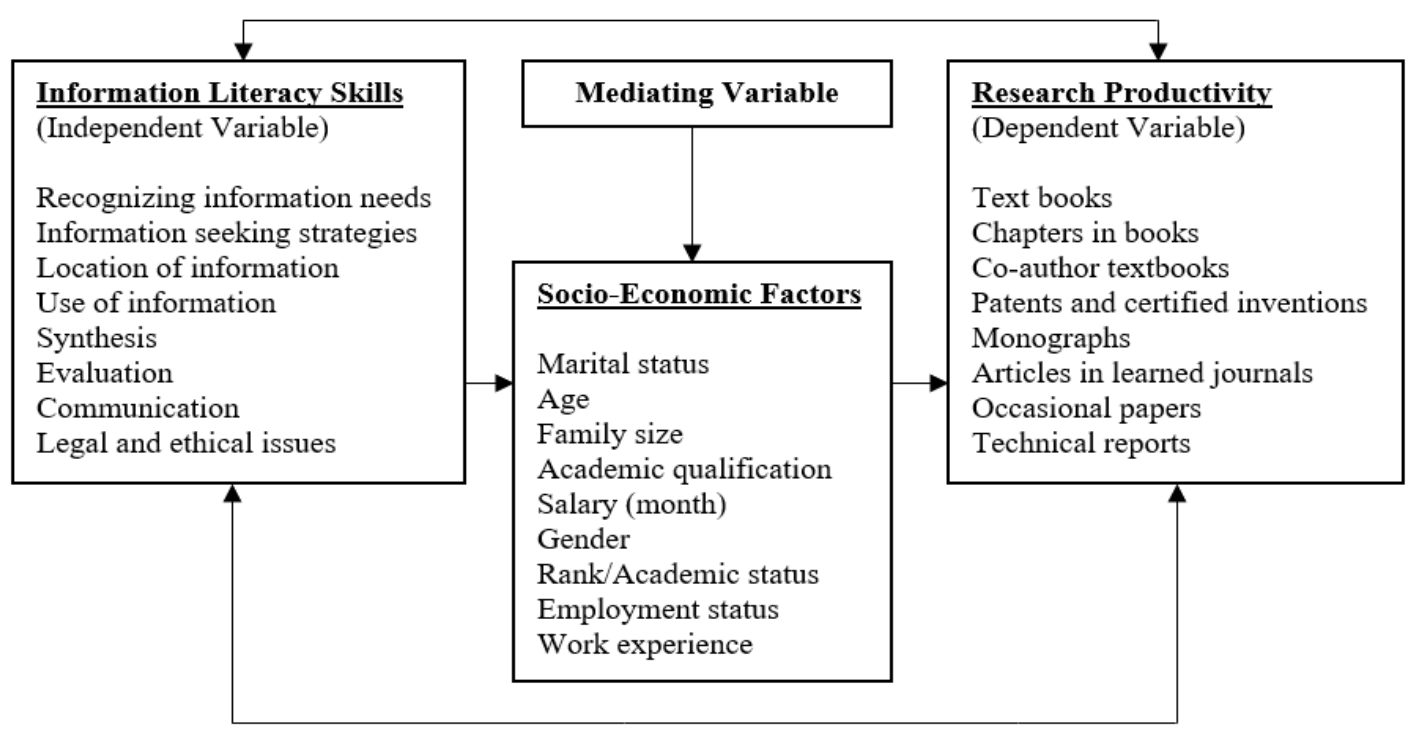

Figure 1. Conceptual model of ILS, socio-economic factors and research productivity of academic staff

The research hypotheses were:

1. There is no significant relationship between ILS and research productivity of academic staff in research institutes in South West Nigeria.

2. Socio-economic factors do not have mediating effects on the relationship between information literacy skills and research productivity of the academic staff.

\section{CONCEPTUAL MODEL OF THE STUDY}

The conceptual model represented in Figure 1 proposes linkages and interactions between the independent variable and dependable variable of this study. The independent variable is ILS while the dependent variable is the research productivity of the academic staff. The mediating variable is the socio-economic factors which mediate between ILS and research productivity.

ILS includes the ability to:

- recognize that information is needed

- understand and articulate scope of information needs

- search strategies in various types of sources in print and electronic resources

- locate information sources using information access tools

- understand and use the various sources of information effectively

- synthesize and blend newly-gathered information with previous information,

- organize and analyze information in a new way

- evaluate, that is, ability to determine the authority, bias, timeliness and relevance

- communicate information tailored to a particular audience in an effective format.

Research productivity comprises number of books, chapters in books, journal articles, monographs, conference papers, workshop papers, conference proceedings, technical reports, patents and occasional papers. All the socio-economic factors (age, gender, academic status, work experience, employment status, family size, marital status and salary) in this model are mediating between ILS and research productivity. 
According to Baron and Kenny (1986), mediating variable specify how or why a particular relationship occurs. Mediators describe the psychological process that creates the relationship and explain how external events take on internal psychological significance. Baron and Kenny (1986) further postulated several criteria for the analysis of a mediating effect. There are steps to examine the mediating effects. Firstly, there is a significant correlation between the independent and the dependent variable. Secondly, the independent variable must be significantly associated with the mediator which predicts the dependent variable. Thirdly the correlation between the independent and dependent variable must be eliminated or reduced when the mediating factor is simultaneously entered.

\section{LITERATURE REVIEW}

\section{Research Productivity Among Academic Staff}

Print and Hattie (1997) defined research productivity as the totality of research performed by academics in universities and related contents within a given time period (p.454). Research efficiency has been defined as the productivity of research per unit of input resource (Kostoff, 1995) which is captured as the product of academic lecturers' research (Carnegie Foundation, 1991). Williams (2003) noted that research productivity could be defined in terms of research product and research effort produced by researchers.

According to Creswell (2014), the most frequently used measure for the quantity or amount of research productivity is a numerical publication count over a certain time period. Most studies measure productivity by calculating a composite indicator derived by summing the number of finished research reports, published reports and utilized research reports. Research capability is measured against the number of department of higher education accredited research output ascribed to an institution and the number of national research foundation-rated researchers associated with an institution (Sedakiwa, 2008). In support, Hadjinicola and Soteriou (2005) claim that research productivity in academic institutions is reflected in the number and quality of articles published by the affiliated faculty.

Creswell (2008) stated that research output is not only meant for solving practical problems but it also provides opportunities in acquiring new ideas that will help to improve human understanding, social, economic and cultural phenomena. Sulo, Kendagor, Kosgei, Tuitoek and Chelangat (2012) submitted that research plays a key role in the development and dissemination of knowledge and that it leads to the development of new knowledge as well as contributing to existing knowledge. Furthermore, it also provides an important background for academic staff to become successful, as they are from documented studies that have been done by other researchers. Research productivity plays a major role in defining success in academic circles, as it is related to promotion, tenure and salary of academic staff (Okonedo, 2015).

\section{Information Literacy Skills of Academic Staff}

Numerous definitions of information literacy can be found in the literature. According to Sayed (1998, p. 14), information literary skills refer to the ability of learners to access, use and evaluate information from different sources, in order to enhance learning, solve problems and generate new knowledge. In the view of Bruce (1995), ILS is the ability to access, evaluate and use information from a variety of sources. Behrens (1994) added to this definition by emphasizing that information literacy lies at the higher end of the literacy continuum - information literacy entails the application of higher order cognitive skills such as synthesizing and evaluating information which has been gathered through basic location 
skills. Information literacy thus refers to a person's ability to apply particular information handling skills in order to locate and utilize information from any resource efficiently and effectively.

Madu and Dike (2012) argued that the information gap, created by rapid technology change and proliferation of information resources, has made it necessary to look for new ways and abilities to use information effectively, especially for research among the academic staff members. Academics with low ILS may spend too much time retrieving information owing to problems they may encounter when seeking information especially in electronic information resources. It is notable as well that the availability of electronic resources does not translate directly into accessibility and eventual use by information users, for example, Kinengyere (2007) found that available information is not necessarily accessed and used by users. The availability of information does not necessarily mean actual use because the users may not be aware of the availability of such resources, how to access them or do not know what the resources offer. Access without skills is not useful, so the acquisition of ILS becomes a basic need of every citizen including the academic staff.

There are indications that academics are readily using online databases made available by their libraries in Nigerian universities (Aduwa-Ogiegbaen \& Stella, 2005; Ureigho, Oroke, \& Ekruyota, 2006; Osunade, Phillips, \& Ojo, 2007; Popoola, 2008). Bhukuvhani, Chiparausha and Zuvalinyenga (2012) however added that academics' understanding of the influence of improved access to digital information resources in general is limited and similar trend is noticeable regarding the mechanisms that mediate between the increased provision of digital material and its use for scholarly work. It is obvious that information users of today, including academic staff, need to be equipped with ILS to be able to effectively, feel the need, access and use information that abounds in this information age. This notion was supported by Okiki and Mabawonku (2013) that the need to find, evaluate and effectively use information has always been associated with academic staff. It was observed that with increased understanding of the learning process and Internet access to unedited works, the academics in Nigerian universities are faced with diverse and abundant information choices. They added that academic staff need complementary cluster of abilities necessary to use information effectively. Bawden and Brophy (2005) observed that many lecturers assumed that they have sufficient ILS for their information needs and are not interested in updating those skills, although they admit that looking for information is a daily activity.

\section{ILS and Research Productivity of Academic Staff}

It is evident from the literature that access to electronic information resources can immensely improve academics' research productivity. However, nagging challenges such as limited access, lack of knowledge and lagging behind in technological advancements has been noted, hence the need for training of lecturers in electronic information resources skills (Bhukuvhani et al., 2012). There are empirical evidences that frequent use of electronic resources for information retrieval and communication is associated with the increase in publication by academics in terms of quality and quantity (Ergart, 2002; Lin, 2001; Manda \& Nawe, 2008; Barjak, 2006; Rowlands \& Olivieri, 2007; E-Journals, 2011).

Academics with low ILS may spend too much time retrieving information due to problems they might encounter while seeking information especially in electronic information resources. To retrieve information in the open Web, academic staff need ILS. There is evidence from information systems research that frequent Internet use for information retrieval and communication is associated with increase in publications by scientists in terms 
of both quality and quantity (Barjak, 2006; Kyrillidon, 2001; Lin, 2001). It has also improved scholarly works in other ways (Rowlands \& Olivieri, 2007; E-Journals, 2011). Noticeably, Barjak (2006) revealed that information retrieval from electronic journals and full-text databases correlate positively with the number of journal articles, conference presentations and reports published.

On the relationship between information literacy competencies and academic productivity, Founad (2000) asserted that access to sophisticated information tools without a conceptual base for use will result in the diffusion of meaningless research efforts. According to him, critical inaccessibility on the other hand, deals with the users' inability to analyze and evaluate the currency of the material. The implication of Founad's assertion is that access to information depends on the knowledge of where to locate information as well as ability to evaluate and analyze information for use. Explaining the above findings, Wilson (2001) argued that the tremendous increase in the need for information literacy for academic productivity was not unconnected with the exponential growth of information engendered by digital information. Information literacy is considered an important element in educational and professional settings, and, in particular, the research endeavor of the academic staff. Accordingly, Omolewa (2008) an academic must have access to wide range of information resource and keep abreast of development in his field. All these could be achieved only when academic staff members are information literate.

Nwosu, Obiamalu and Udem (2015) investigated the relationship between the ILS of 1,038 academic staff in Nnamdi Azikiwe University, Awka, Nigeria, using correlation research design. Their study submitted that the level of ILS possessed by the academic staff is moderate. The test for hypothesis indicates that there is a significant and positive relationship in the level of ILS possessed by the academic staff and their ranks. The test also shows that there is significant and positive relationship in the research output and the rank of lecturers' in the university. There is also significant relationship between the ILS possessed by the academic staff and research output while the test further indicates that there is positive correlation between their ILS and their research output.

\section{Socio-Economic Factors and Research Productivity of Academic Staff}

Several studies have addressed socio-economic factors influencing research productivity (Bozeman \& Corley, 2004). One of the determinants is gender which has been featured in numerous studies with mixed results (Blackburn, Bieber, Lawrence, \& Trautvetter, 1991). The variations in research productivity available in the scholarly world, between men and women, have always attracted the interest of many researchers across the globe (Lone \& Hussain, 2017). The findings of Lone and Hussain (2017) clearly depict that comparatively, males have a higher average productivity than females for all the performance indicators especially research productivity, patent creation, funding and collaboration across regions and disciplines. However, the gap is narrowing with the passage of time. The researchers have noted many factors, personal as well as academic, that are responsible for the limited productivity of women in research. Age, marriage, children and domestic workload are some personal factors badly affecting research productivity of women whereas less representation of women in higher education, low academic ranks, and fewer research funds are some of the academic factors affecting the research productivity negatively. (Lone \& Hussain, 2017).

According to some studies, men researchers are significantly higher than women in all the research fields especially engineering (Glover, 2002), technology (Mauleon \& Bordons, 2010), math-intensive fields (Ceci \& Williams, 2010) and technology (Sotudeh \& Khoshian, 
2013). Pudovkin, Kretschmer, Stegmann and Garfield (2012), Frandsen, Jacobsen, Wallien, Brixena and Ousagere (2015) and Ebadi and Schiffauerova (2016) also confirmed that men published more than female. Similarly, Lariviere et al. (2011) reported that while male researchers in the field of health in Quebec (Canada) universities published 19 articles on average from 2000-2008, female researchers published 12 articles. In nature science and engineering, there is a $20 \%$ difference (19 versus 13 articles) and in social science and humanities, a 40\% difference (32 versus 23 articles). In other studies, Frandsen et al. (2015) and Ebadi and Schiffauerova (2016) depicted that the average total number of publications is slightly higher for men than for women.

Many studies have explained why women do not make much progress like men. The factors responsible are most often divided into three categories - institutional climate that is inhospitable to women; a restrictive research culture that discounts gendered topics; and the dual pressures of starting a family while trying to achieve tenure (American Political Science Association, 2005; Erickson \& Prügl, 2010; Sarkees \& Henehan, 2010; Cowden, McLaren, Plumb, \& Sawer, 2012; Williams \& Ceci, 2012). However, some researchers found that there was no gender difference in productivity (Teodorescu, 2000; Williams, 2000), while other studies in the German sociology field demonstrated that the proportion of female researchers is increasing due to the influence of gender equality policies and that females have greater chances of achieving tenure than males after women developed coping strategies (JungbauerGans \& Gross, 2013; Lutter \& Schröder, 2016).

Several studies on research productivity have indicated that the relationship between career publication and age is not linear, although the overall rate of publication generally declines with age (Finkelstein, Seal, \& Schuster, 1998; Teodorescu, 2000). Williams (2000) studied academic staff in the Human Resource Development Faculty in the United States and found no significant relationship with age, as earlier done by Ramsden (1994) in Australia. Notably, a category of researchers suggested that the productivity of academics follows a cyclical pattern. At the beginning of their careers, people in academic life devote more time to their research activities and produce more to build reputation in order to maximize their welfare in the future. As they approach their retirement, with no incentive any longer to build for their future, they change their time allocation and concentrate more on non-research activities and their productivity declines. (Levin, 1991). There are studies that diverge from this quadratic pattern. For example, Diamond (1985) found a linear negative relationship between age and quantity and quality of research whereas Carayol and Matt (2006) found no significant relationship between age and academic performance.

Kwiek (2018) affirmed that the growing scholarly interest in research top performers comes from the growing policy interest in research top performance itself. He studied research productivity of the upper $10 \%$ of Polish academics using a bivariate analysis of their working time distribution and their academic role orientation, as well as through a model approach. The author presented odds ratio estimates with logistic regression of highly productive Polish academics being presented. Consistently across major clusters of academic disciplines, the tiny minority of $10 \%$ of academics produces about half (44.7\%) of all Polish publications (48.0\% of publications in English and 57.2\% of internationally co-authored publications).

Academic research productivity has been widely investigated and found that several factors, such as the quality of doctoral training (Lyytinen, Baskerville, Livari, \& Te'eni, 2007) seniority and mentorship (Bentley, 2012), serve as predictors of research output of academic staff. It is noteworthy that many socio-economic factors predict research productivity (Bentley, 2012; Jonkers \& Tijssen, 2008; Lyytinen et al., 2007) in response to 
the dynamics of institutional, national and regional research, and publishing cultures. However, Kotrlik et al. (2002), Williams, Bartlett, Kotrlik and Higgins (2002), and Williams (2003) stated that there was no significant relationship between them.

In several studies, rank was found to be related to research productivity (D'Amico, Vermigli, \& Canetto, 2011; Hesli \& Lee, 2011). D'Amico, et al. (2011) reported that full professors published more in local outlets than assistant professors but not more than associate professors. Full professors also produced more in international outlets than both assistant and associate professors. They are known to be more involved in networking to promote publications and more likely to have research resources that facilitate publishing. Furthermore, full professors probably have access to external grants, which are regarded as one of the best predictors of productivity (Lee \& Bozeman, 2005). Leahey (2006), however, found that productivity decreased as rank increased. This tends to indicate that, since they have gone past worrying about tenure or achieving higher rank, the motivation of senior faculty members to publish decreases as they are offered lesser rewards for high productivity. Chen, Gupta and Hoshower (2006) studied 320 university professors who taught in business school to explore their perceptions about important factors of research article production. Their findings revealed that assistant professors tend to be influenced by external rewards, such as promotion and money, but associate professors tend to be influenced by their internal psychological feelings.

Kotrlik et al. (2002) revealed that work experience is a significant determinant of research productivity in terms of quantity and quality while Hedjazi and Behravan (2011) affirmed that experience in college teaching allows exposure to contemporary empirical and theoretical literature. The analysis result of study of research productivity of academics in Jigjiga University, Ethiopia done by Teka Feyera, Habtamu Atelaw, Najib Abdi Hassen and Gemechu Fufa (2017) indicated that there was statistically significant $(\mathrm{p}<0.05)$ variation in publication productivity in relation to years in academic profession, highest degree earned and academic rank of the respondents. Similarly, faculty members, with track records on research grant winning, theses supervision, attendance of academic conferences and research related trainings, were more likely to publish $(\mathrm{p}<0.05)$ as against those who did not have such experience. However, there was no statistically significant difference $(\mathrm{p}>0.05)$ in publication productivity in relation to sex, age, teaching load and involvement in administrative activities. In addition, significant variation $(\mathrm{p}<0.05)$ existed in publication productivity across academic disciplines. Faculties in the natural and life science fields generally appeared to publish more than those in the social sciences.

Bartlett, Kotrlik and Higgins (2001) found that the number of years a faculty member held a tenure track position did not explain a significant portion in variance for research productivity. Similarly, Antony and Raveling (1998) compared faculty productivity among tenured and non-tenured faculty members, and found a difference in workload among them. These results are consistent with findings of Bland, Center, Finstand, Risbey and Staples (2005). However, Qung and Grandom (2000) and Teodorescu (2000) found no effect of tenure in productivity.

Kyvik and Aksnes (2015) in a study of Norwegian research universities reported that there has been an increase in scientific and scholarly publishing over the last 30 years. The study explained the reasons for this growth in a generational perspective. According to the authors, this was due to better qualified new generations of academic staff, the increase in research collaboration, improved funding and research conditions and the introduction of incentive systems. In addition, a general change in norms for appropriate academic contributes to explaining the productivity increase. Okendo (2018) conducted a study on 
constraints of research productivity in Mwenge Catholic University. The study, guided by the expectancy theory which relates how individuals are motivated due to expected outcomes, concluded that resource, institutional and cultural constraints have a considerable influence on the research productivity in the university.

Research has long established that women are more likely than men to interrupt their careers to have children. This finding holds for a variety of fields and disciplines (Dozier, Sha, and Okura 2007; Mathews \& Hamilton 2009; Bertrand, Goldin, \& Katz, 2010). Similarly, Usang, Basil, Udida and Udey (2007), in their study of academic staff research productivity in universities in the South West zone of Nigeria, reported that male and female academic staff differed significantly in their research productivity; married and single academic staff differed significantly in their research productivity and there is a significant influence by areas of specialization on academic staff research productivity. It was recommended that academic staff in universities should be encouraged to carry out research work irrespective of gender, marital status and area of specializations.

Several studies reported that there is relationship between research productivity and salary (Jacobsen 1992, Preffer \& Langston, 1993; Tornquist \& Kallen, 1992), and this is expected, since salary often reflects research productivity levels. Tasli, Kacar and Aydemir (2012) revealed that scientific productivity is closely related to gross income, population, and cultures of the countries and, as such, every country has a responsibility to contribute to science. Whiston and Geiger (1992) reported that large funds are distributed to the universities according to their capacity to conduct fruitful research, quality of facilities, presence of research staff and graduate students. In the same vein, Obibuaku (2005) also viewed research productivity from the monetary point of view. According to him, research entails a lot of efforts and it is capital intensive. He argued that if an academic staff member is to carry out research with the purpose of publishing it in reputable journals outside the country, there is need to have financial resources and laboratory equipment required to accomplish the purpose. Field-specific patterns and trends can affect faculty's research productivity.

Although some scholars (White et al., 2009) quite rightly argued that differences in the nature of the products produced across disciplines would make direct comparison of productivity difficult literature asserts that there is considerable differences between the publication productivity of physical/biological scientists and social scientists/humanists (Stack, 2004; Shin \& Cummings, 2010; Sabharwal, 2013).

Bai and Hutton (2011) studied 182 Chinese TEFL (Teaching English as a Foreign Language) academics' research outputs and perceptions about research across three Chinese higher education institutions using a literature-based survey. ANOVA, t-tests and descriptive statistics were used to analyze data from and between the three institutions. The findings indicated that more than 70 per cent of the TEFL academics had produced no research in 10 of the 12 research output fields during 2004 to 2008. The English Language and Literature Department in the national university out-performed all other departments at the three institutes for most of the research output categories. While a majority of the participants seemed to hold positive perceptions about research, t-tests and ANOVA indicated that their research perceptions were significantly different across institutes and departments.

Pau et al. (2017) investigated participation in dental research activities in Malaysia, and its association with socio-demographic and professional characteristics, and perceptions of research and development $(R \& D)$ culture. They found among other things, that R\&D skills and aptitude were associated with older respondents $(0.050), \mathrm{PhD}$ qualification $(0.014)$ and more years in academia (0.014). R\&D intention was associated with any of the socio- 
demographic characteristics. Thirty (23.4\%) respondents reported a peer review research publication in the past 12 months, which was associated with having a $\mathrm{PhD}$ (OR 12.79, CI 1.28-127.96), after adjustment in regression analyses.

Saimroh (2017) empirically examined the effect of researcher characteristics, subjective well-being, knowledge sharing and research competence on research productivity of 100 Indonesian researchers in the Agency for Research and Development and Training scattered in central and local units. The results of ANOVA concluded that the productivity did not differ significantly by gender. However, there were significant differences in the research productivity based on the academic qualification and the functional job of researchers. The results of path analysis concluded that subjective well-being and research competence had direct positive effect on the research productivity, knowledge sharing had direct negative impact on the research productivity but indirect positive effect through the research competence on the research productivity.

Wills, Ridley and Mitev (2013) investigated factors considered to impact the research productivity of accounting academics, and identified how the factors were related. Three clusters of factors that were found to have had most focus in related studies over the period. These were institutional characteristics, intrinsic motivation and knowledge, skills and other individual characteristics. Hierarchical clusters of factors operating at government, institution and individual levels appeared to influence the research output of accounting academics.

Kumar and Dora (2012) reviewed the research performance of the Indian Institute of Management Ahmedabad based on the papers published in journals that have been indexed in Web of Science and Scopus for the past 12 years. The authors attempt to identify the trends in research output over the period 1999 to 2010 that includes types of publications, most preferred journals, most prolific authors from IIMA, authorship pattern, and the journals most cited by the researchers from IIMA. The findings throw interesting facts like increase in the number of papers being published by IIMA over the years (1999 to 2010), increase in collaborations among authors, decrease in single author publications and multidisciplinary nature of research undertaken at the Institute. To find out the productivity and publication behavior of the researchers of Tata Institute of Social Science (TISS), Koganuramath et al. (2002) analyzed 663 papers published by the scientists from 1990 to 2000, and provided the collaboration pattern, identified prolific authors and core journals that were most preferred for publication by the scientists. The main objective of this study was to provide a bird's eye view of the productivity of TISS scientists and their specializations.

\section{METHODS}

A descriptive survey research design of the correlation type was adopted for this study. The population of the study is 782 academic staff from 12 research institutes in South West Nigeria. This includes all the 746 research fellows and 36 academic librarians in the 12 research institutes. The research institutes were established by the Federal Government of Nigeria and the appointment and conditions of service of researchers are in line with the Federal Civil Service Scheme of Nigeria. According to the Scheme of Service published by the Office of Head of Service of the Federation, researchers and librarians in the research institutes surveyed in this study are categorized as academic staff members.

Academic librarians are included as respondents in this study because in Nigeria they are accorded academic status (Ochai, 1998, Egunjobi, 2001). Research productivity is very important in the appointment and promotion of academic staff of these institutes as it is spelt out in the Schemes of Service. By virtue of their work and positions, apart from educational 
qualifications and cognate experience, researchers and librarians who are respondents in this study are required to get evidence of satisfying research publications in reputable journals, conference proceedings and seminar papers for appointments and promotions (Federal Republic of Nigeria, 2000). The number of publications varies with different academic positions in the research institutes and the possession of a $\mathrm{PhD}$ in the relevant field is a prerequisite for appointment as Principal Research Officer in these institutes (Federal Republic of Nigeria, 2000). Total enumeration technique was adopted for this study, as the total population academic staff (researchers and academic librarians) in the 12 research institutes is not too large.

\section{Data Collection Instrument}

The research instrument used for the study was a structured questionnaire, referred to as the ILS, Socio-economic Factors and Academic Research Productivity Questionnaire (ILSSEFRPQ). The questionnaire was designed and validated. The instrument is made up of the following sections:

- Section A: Demographic and socio-economic factors of the respondents: This section elicits socio-economic variable listed in the conceptual model that may affect the research productivity of the respondents.

- Section B: ILS scale of the academic staff: The scale comprising 40 ILS items was developed by Kurbanoglu, Akkoyunlu and Umay (2004). The items request respondents to indicate the extent of their ILS, and questions are asked on the eight main ILS categories in the conceptual model. The statements in the scale are rated on a five-point Likert Scale. The instrument has a reliability coefficient of 0.96 after revalidation by the researcher, signifying that the scale is reliable.

- Section C: Research productivity scale of the academic staff of the research institutes: The research productivity scale developed by Popoola (2008) with test-retest reliability coefficient $(\alpha=0.72)$ was used after revalidation (test-retest reliability coefficient of 0.78 ) to determine research productivity of the academic staff. The instrument with 0.75 reliability coefficient has also been used by Okiki (2013). Questions asked include the quantity and pattern of research productivity in terms of publications they have in the form of books, journal articles, monographs, chapters in books, collaborated works, occasional papers, technical reports, scientific peer-reviewed, conference proceedings, patents and certified inventions.

\section{Validity and Reliability of the Instrument}

To ensure the content and face validity, ten copies of the questionnaire were given to five experts in library and information science, lecturers from other departments and researchers in Babcock University, University of Ibadan and Tai Solarin University of Education in Nigeria. The experts' suggestions in terms of ensuring content validity in the area of the socioeconomic factors that could be measured, components of ILS and various forms in which research productivity could be measured, were incorporated in the questionnaire. To ensure content validity of the instrument, 30 copies of the questionnaire were pre-tested on the academic staff of National Center for Agricultural Mechanization, Ilorin, Kwara State, Nigeria and the data was subjected to reliability analysis using the Cronbach's Alpha method. 
The ILS test has a reliability coefficient of 0.96 using Cronbach's Alpha method; while research productivity has a reliability coefficient of 0.80 using test-retest method.

\section{Data Collection Procedure}

Researchers and six trained research assistants administered the questionnaire to the respondents. The research assistants were trained on what were expected of them in the field, to minimize unnecessary mistakes. They were also trained on how to explain grey areas in the instrument to respondents in the course of administering the questionnaire.

In order to facilitate the administration and retrieval of the questionnaire, copies of questionnaires were channeled to respondents through the Office of Executive Directors of these research institutes. Researchers and research assistants paid several visits to these institutes for the distribution, monitoring and retrieval of the questionnaire. The field work of the researchers took about five months that is between August and December 2018. Out of the total of 782 copies of the questionnaire administered on academic staff, 665 were retrieved and of these, 55 copies collected not fully completed by the respondents were dropped from the analysis. 610 copies were used for the analysis, yielding a response rate of $78 \%$.

\section{RESULTS}

Table 1 shows the demographic data of the respondents. Data gathered showed that majority of the respondents 324 (53.1\%) were Master's Degree holders. The result indicates that majority of the respondents 196 (32.1\%) were Senior Scientists. The result of the study shows that majority of the respondents, $81 \%$ of them were within lower and middle of academic career. It further shows that $74.2 \%$ were not $\mathrm{PhD}$ holders. These results have implications for manpower planning and staff development of the research institutes, since researchers and academic librarians are in the academic positions cadre of the institutes, the possession of $\mathrm{PhD}$ is pre-requisite for the attainment of many senior posts in the institutes. The implication is that the institutes should be prepared to encourage some of the academic staff for $\mathrm{PhD}$ programmes in future so that they could reach self-actualization in the research institutes and their research productivity could be enhanced in these research institutes.

Gender results indicates that 308 (50.5\%) were female while the males were less with $302(49.5 \%)$. Those within the age range of 31-40 years constitute the highest number of respondents of the study at $267(43.8 \%)$.

The result on age distribution of the respondents showed that majority (505) were within age ranged of 31-50 years which is the average working range. In addition, it was revealed that younger generation (21-30 years) was least represented at $8.2 \%$ while those very close to retirement age constituted $9 \%$. The implication of this is that performance of academic staff in research productivity is expected to be higher since the majority was in average working age. In addition, the management of the institutes need to take cognizance of raising the proportion or percentage of younger generation (21-30 years) employed as academic staff. Also, the findings show that, a total of 508 respondents (83.3\%) were married, while $8.7 \%$ were singles. This is expected as about $92 \%$ of the respondents were above 30 years - they are expected to have gotten married going by Nigerian social norm and culture. The majority of the respondents (92.5\%) of the academic staff were within the lower and middle salary scales. About $81 \%$ of them were within the lower and middle of their academic career in the institutes. The inference from these findings is that the majority of the respondents were within the lower rank and this might also have influence on the level of 
research productivity of the academic staff in the research institutes surveyed especially when the literature review suggests that research productivity is a function of rank and salary of academic staff.

Table 1. Descriptive analysis of demographic data $(\mathrm{N}=610)$

\begin{tabular}{llcc}
\hline \multicolumn{2}{c}{ Data Description } & Frequency & Percent \\
\hline Academic Qualification & Master's Degree holder & 324 & 53.1 \\
& PhD & 151 & 24.8 \\
& M.Phil & 54 & 8.9 \\
& Bachelor's Degree & 52 & 8.5 \\
& PGD & 29 & 4.8 \\
\cline { 2 - 4 } & Total & 610 & 100 \\
\hline Academic Status & Senior Scientist & 216 & 32.1 \\
& Principal Scientist & 104 & 17.04 \\
& Research Scientist I & 103 & 16.9 \\
& Assistant Director & 45 & 9.7 \\
& Research Scientist II & 59 & 7.4 \\
& Research Fellow I & 29 & 4.8 \\
& Research Fellow II & 23 & 3.8 \\
& Academic Librarian & 22 & 3.60 \\
& Deputy Director & 9 & 1.5 \\
\hline Total & 610 & 100 \\
\hline Gender & Female & 308 & 50.5 \\
& Male & 302 & 49.5 \\
& Total & 610 & 100 \\
\hline Age & $21-30$ & 50 & 8.2 \\
& $31-40$ & 267 & 43.8 \\
& $41-50$ & 238 & 39.0 \\
& 51 and above & 55 & 9.0 \\
\hline
\end{tabular}

Table 2. Test of significant relationships between research productivity and independent variables of the respondents $(\mathrm{N}=610)$

\begin{tabular}{llc}
\hline Variables & & Research productivity \\
\hline Recognizing information needs & Pearson Correlation & .445 \\
& Sig P & .002 \\
Information seeking strategies & Pearson Correlation & .434 \\
& Sig P & .006 \\
Location of information & Pearson Correlation & .373 \\
& Sig P & .010 \\
Use of information & Pearson Correlation & .448 \\
\multirow{2}{*}{ Synthesis } & Sig P & .000 \\
\multirow{2}{*}{ Evaluation } & Pearson Correlation & .389 \\
\multirow{3}{*}{ Communication } & Sig. P & .028 \\
& Pearson Correlation & .475 \\
Legal/ethical issues & Sig. P & .004 \\
& Research productivity & .418 \\
& Sig. P & .003 \\
& Pearson Correlation & .418 \\
& Sig. P & .003 \\
\hline
\end{tabular}


Table 3. Interrelationships matrix showing Pearson's zero order relationships among socioeconomic factors, information literacy skills, and research productivity of the respondents

$(\mathrm{N}=\mathbf{6 1 0})$

\begin{tabular}{|c|c|c|c|c|c|c|c|c|c|c|c|c|c|}
\hline Variables & Mean & SD & 1 & 2 & 3 & 4 & 5 & 6 & 7 & 8 & 9 & 10 & 11 \\
\hline $\begin{array}{l}1 \text { Monthly } \\
\text { salary }\end{array}$ & 1.36 & .67 & 1 & & & & & & & & & & \\
\hline $\begin{array}{l}2 \text { Academic } \\
\text { status }\end{array}$ & 4.50 & 2.28 & $.10^{*}$ & 1 & & & & & & & & & \\
\hline 3 Gender & 1.50 & .50 & -.03 & $.16^{* *}$ & 1 & & & & & & & & \\
\hline 4 Age & 2.49 & .77 & .00 & .08 & .02 & 1 & & & & & & & \\
\hline $\begin{array}{l}5 \text { Highest } \\
\text { Academic } \\
\text { Qualification }\end{array}$ & 2.8 & 1.86 & $-.14^{* *}$ & .05 & .03 & -.05 & 1 & & & & & & \\
\hline $\begin{array}{l}6 \text { Work } \\
\text { experience }\end{array}$ & 1.93 & .69 & $.11^{* *}$ & -.06 & .05 & .05 & -.04 & 1 & & & & & \\
\hline 7 Marital status & 1.17 & .37 & -.02 & .07 & $.22^{* *}$ & -.03 & $.09^{*}$ & $-.11^{* *}$ & 1 & & & & \\
\hline $\begin{array}{l}8 \text { Nuclear } \\
\text { family size }\end{array}$ & 1.08 & .27 & .03 & -.07 & .02 & .03 & -.04 & .05 & .03 & 1 & & & \\
\hline $\begin{array}{l}9 \text { Nature of } \\
\text { employment }\end{array}$ & 3.00 & .25 & $-.08^{*}$ & $-.16^{* *}$ & -.01 & -.01 & -.02 & .07 & -.05 & .03 & 1 & & \\
\hline 10 ILS & 147.82 & 41.96 & -.06 & $.47^{* *}$ & -.08 & .07 & -.01 & .02 & $.33^{* *}$ & .0 & $.42^{* *}$ & $.22^{* *}$ & 1 \\
\hline $\begin{array}{l}11 \text { Research } \\
\text { productivity }\end{array}$ & 11.51 & 2.36 & $-.43^{* *}$ & $-.44^{* *}$ & $.46^{*}$ & $-.32^{*}$ & $-.31^{*}$ & $-.34^{* *}$ & $.44^{* *}$ & $-.37^{* *}$ & $-.33^{* *}$ & $.49^{* *}$ & $.56^{* *}$ \\
\hline
\end{tabular}

Notes: * Correlation is significant at the 0.05 level (2-tailed)

** Correlation is significant at the 0.05 level (2-tailed)

Hypothesis 1. There is no significant relationship between ILS and research productivity of academic staff in research institutes in South West Nigeria.

Table 2 shows the relationship among the various components of ISL and research productivity. The results indicate significant relationships among all the components of ILS.

The relationship between ILS and research productivity of academic staff in the research institutes in South West Nigeria is shown in Table 2. The result indicates a significant relationship between ILS and research productivity $(r=0.557, p<0.05)$, hence the null hypothesis is rejected.

Hypothesis 2. Socio-economic factors do not have a mediating effect on the relationship between ILS and research productivity of academic staff of research institutes in South West Nigeria.

Table 3 presents how our analysis met conditions stated by Baron and Kenny (1986) for mediation occurs. The first condition that the independent variable (ILS) should correlate with mediators (socio-economic factors) is met by our analysis as the result shows significant correlation between ILS and socio-economic factors: academic status $(\mathrm{r}=0.47)$, marital status $(\mathrm{r}=0.33)$, nature of employment $(\mathrm{r}=0.42)$. The second condition for mediation to occur 
Table 4. Hierarchical regression analysis of research productivity of respondents

\begin{tabular}{c|l|c|c|c|c|c|c}
\hline Step & Variables & Beta & T & Adj. R & $\begin{array}{c}\text { Change } \\
\text { in R }\end{array}$ & F & Sig. P \\
\hline 1 & Information literacy skills & 0.82 & $2.91^{*}$ & .15 & .15 & 4.077 & .044 \\
\hline 2 & Monthly Salary & -.020 & $3.489^{*}$ & .35 & .20 & 3.611 & .020 \\
& Academic Status & -0.93 & $-2.98^{*}$ & & & & \\
& Gender & .084 & 1.97 & & & & \\
& Age & -.028 & $-3.68^{*}$ & & & & \\
& Highest Academic & -.026 & $2.63^{*}$ & & & & \\
& Qualification & -.018 & $3.438^{*}$ & & & & \\
& Work Experience & .002 & .05 & & & & \\
& Marital Status & .011 & .27 & & & & \\
& Nature of Employment & -.072 & -1.76 & & & & \\
& Nuclear Family Size & -.112 & $3.86^{*}$ & .47 & .12 & 4.891 & .013 \\
\hline 3 & ILS*MONTHLY SAL & -.381 & $-2.37^{*}$ & & & & \\
& ILS*AS & -.134 & $2.76^{*}$ & & & & \\
& ILS*AGE & .016 & $3.14^{*}$ & & & & \\
& ILS*EDC & .206 & $3.40^{*}$ & & & & \\
& ILS*WE & -.324 & $-2.73^{*}$ & & & & \\
& ILS*NE & -.102 & -.517 & & & & \\
& ILS*NFS & -.113 & -.578 & & & & \\
& ILS*GENDER & .612 & 2.876 & & & & \\
& ILS*MS & & &
\end{tabular}

Notes: $* \mathrm{P}<0.05$ significant

was also met as the result shows that there is significant relationship between ILS and research productivity $(\mathrm{r}=0.56)$ of the academic staff of the research institutes. Hence, our result met the second condition set for mediation to occur.

The third condition that the mediators (socio-economic factors) must correlate with the dependent variable (research productivity) was also met as the result shows significant relationships between research productivity and: monthly salary $(\mathrm{r}=-0.43$,); academic status $(\mathrm{r}=-0.44)$, gender $(\mathrm{r}=0.46)$, age $(\mathrm{r}=-0.32)$; academic qualification $(\mathrm{r}=-31)$; work experience $(\mathrm{r}=$ $-0.34)$; marital status ( $\mathrm{r}=-0.43)$; family size $(\mathrm{r}=-0.38)$; and nature of employment $(\mathrm{r}=-0.32)$.

From the results, all the socio-economic factors correlated with research productivity of the academic staff of the research institutes.

The fourth condition is the previously significant effect of predictor variable is decreased to non-significance or decreased in terms of effect size after the inclusion of mediator variable into the analysis. This is demonstrated in Table 2 in the hierarchical regression.

Table 4 presents a summary of the hierarchical regression analysis of research productivity of the respondents.

In the first step, ILS was found to have significant effect on research productivity of the respondents and it accounted for $15 \%$ variance $\left(\operatorname{adj} \mathrm{R}^{2}=0.15\right.$ ) in explaining the research productivity of the respondents.

In the second step, when socio-economic factors were entered, monthly salary (Beta=0.020 ), academic status (Beta $=-0.093$ ), age (Beta $=-0.028)$, highest academic qualification (Beta $=-0.026$ ), and work experience (Beta $=-0.018$ ) were found to have significant effect on 
research productivity of the respondents. All these account for 35\% variance in explaining the research productivity of the respondents (change in $\mathrm{R}^{2}=0.20$ ) while gender (Beta $=0.084$ ), marital status (Beta $=0.002)$, employment nature $(B e t a=0.011)$ and nuclear family size $(B e t a=-$ 0.072) do not have significant relationship on research productivity of the respondents.

In the third step, mediating effects of socio-economic factors on ILS in explaining research productivity of respondents were revealed. The interactive effects of each socioeconomic factor with ILS are shown so that the mediating effects are revealed conspicuously. When mediating effects of socio-economic factors on relationship between information literacy and research productivity of the respondents were tested in the hierarchical regression, the results showed that monthly salary (Beta $=-0.112$ ), academic status (Beta $=-$ 2.378), age (Beta $=-0.134)$, highest educational qualification ( $\mathrm{Beta}=0.016)$, work experience $($ Beta $=0.206)$ and employment nature (Beta $=-0.324)$ have mediating effects on ILS in explaining research productivity of the respondents. All these accounted for $47 \%$ variance in research productivity of the respondents (change in $\mathrm{R}^{2}=0.12$ ) while family size (Beta $=-0.102$ ), gender $(B e t a=-0.133)$ and marital status $(B e t a=0.612)$ do not have significant mediating effects on relationship between information literacy and research productivity of the respondents.

\section{DISCUSSION AND CONCLUSION}

The study revealed that there is a relationship between ILS and research productivity of the academic staff of Nigerian research institutes. There are significant relationships among each and every component of the ILS and research productivity of the academic staff. This finding is in consonance with the finding of Wilson (2001) who reported that there was connection between information literacy and academic productivity, and this, he argued was brought about by the digital revolution. It is also in line with Armstrong (2005) who established that understanding availability of resources required the researchers to have the ability to identify what and where the resources are available for exploitation, how to access them and the merit of individual resource type which will eventually increase research productivity. This finding also agrees with Okiki and Mabawonku (2013) and Nwosu, Obiamalu and Udem (2015) who submitted that research productivity is significantly influenced by ILS of academic staff in the federal universities in Nigeria.

The study further showed that monthly salary, academic status, age, educational qualification, work experience and employment nature have mediating effects on the relationship between ILS and research productivity of the academic staff. They accounted for $47 \%$ of the variance in relationship between ILS and research productivity of the respondents.

The monthly salary of the academic staff was found mediating in the relationship between ILS and research productivity. Considerable increases in the monthly salary give strength to the existing relationship between the independent variable and the outcome variable, which brings improvement in the research output of the academic staff. This happened as the increase in salary could serve as motivator to increase research productivity for the academic staff.

Academic status of the respondents also served as mediating variable in the relationship between ILS and research productivity. Appreciable improvement in the academic status of the respondents when combined as intervening variable with the existing relationship between ILS and research productivity, the mediator (academic status) strengthened and reinforced this relationship which resulted in the research output improvement of the academic staff in the Nigerian research institutes. Increased academic status would make them more productive at 
conducting research than junior academics as they would be more experienced and likely to larger professional network and be better positioned to draw tangible and intangible resources to support research activities as argued by Abramo, D'Angelo and Di Costa (2011) and Puuska (2010). The established relationship between ILS and research productivity alone is not enough to bring about increase in research output of the respondents with lower academic status. It has to be assisted by improvement in their academic status in order to have increase in research output.

In addition, educational qualification of the academic staff played mediating role in the relationship between ILS and research productivity of the respondents. As the educational qualifications of academic staff increase, the existing relationship between the independent variable and dependent variable is reinforced; this culminates in higher research output of the respondents. It is the interaction of the higher educational qualification with ILS that brings increase in research productivity.

In the same vein, age of the respondents served as a mediating variable in reinforcing the relationship between information literacy and research productivity which then resulted in increase in research output of the academic staff. As the academic staffs increase in age, they gather more experience that enhances their research skills, which improve research performance.

Nature of employment of the academic staff also has mediating effect in the relationship between ILS and research productivity. The types of employment identified among the researchers are full time, contract, part-time/adjunct and sabbatical. When the nature of employment is combined with the existing relationship between the ILS and research productivity, it acts as intervening variable and it interacts with the information to bring increase in research productivity. Furthermore, this study suggests when the employment is full-time there is tendency that interactive effect will be much as research productivity will be enhanced greatly because the full-time academic staff enjoy job security, employment permanency and promotion. This speculation could be investigated further by future research studies. Similarly, work experience of the academic staff also matters in mediating the relationship between the dependent and independent variable. Experience possessed by the respondents as they progress in their career interacts with the independent variable to reinforce the relationship it has with the dependent variable. It is pertinent to mention that it is not automatic that mere establishment of this relationship will be translated to increase in research productivity, until mediating variable (work experience) interacts in the process to produce increased research output.

This study established that, even though there is relationship between ILS and research productivity of the academic staff, this relationship is significantly mediated by monthly salary, academic status, age, highest educational qualification, work experience and employment nature of the academic staff as the interactive effects of these factors affect the relationship that exist between the independent and dependent variable. The mediating roles of these intervening variables are results of significant relationship that exists between them and ILS and the dependent variable (research productivity) of the academic staff as well as the interaction of the socio-economic factors with the ILS. This result shows the importance of the socio-economic factors as they might reduce or even eliminate this relationship (Baron \& Kenny 1986). This then, suggests that any measure that would be introduced by the management of these research institutes to strengthen the relationship between ILS and research productivity of the academic staff, should take cognizance of these socio-economic factors in order to improve research output of the academic staffs in Nigerian research institutes. 
It is noteworthy also that other socio-economic factors, (staff, family size, gender and marital status) do not have significant mediating effects on the relationship between ILS and research productivity of the respondents. This could be attributed to the fact that the relationships among these few socio-economic factors, ILS and research productivity of the academic staff which are not strong enough to have mediating effects in the relationship between ILS and the research productivity of the academic staff of research institutes in South West Nigeria.

\section{CONTRIBUTION TO KNOWLEDGE AND IMPLICATION}

The major contribution to knowledge of this study is that possession of high level ILS is not enough to improve research productivity. Rather, understanding the mediating roles of socioeconomic factors (monthly salary, academic status, age, educational qualification and nature of employment) of the academic staff go a long way in affecting the extent the ILS possessed in enhancing the research productivity of the academic staff surveyed. The implication of this study is that management of these research institutions should take cognizance of the mediating effects of the socio-economic factors which could affect the relationship between ILS and research productivity of the academic staff.

\section{REFERENCES}

Abramo, G., D'Angelo, C.A., \& Di Costa, F. (2011). Research productivity: Are higher academic ranks more productive than lower ones? Scientometrics, 88(3), 915-928.

Aduwa-Ogiegbaen, S.E.O., \& Stella, I. (2005). Extent of faculty members' use of internet in the University of Benin, Nigeria. Journal of Instructional Psychology, 32(4), 69-276.

Altbach, P., \& Lewis, L. (1995). College teachers-attitudes. Change, 27(6), 48-55.

American Library Association. (2008). Concepts of information literacy. Retrieved from http://www.ala.org/acrl/publications/whitepapers/presidential

American Political Science Association (APSA). (2005). Women's advancement in political science: A report on the APSA Workshop on the Advancement of Women in Academic Political Science in the United States. Washington, DC: American Political Science Association.

Antony, J.S., \& Raveling, J.S. (1998). A comparative analysis of tenure and faculty productivity: Moving beyond traditional approaches. Paper presented at the 1998 Annual Meeting of the Association for the Study of Higher Education, (ASHE), Miami, Florida. Retrieved from https://files.eric.ed.gov/fulltext/ED427598.pdf

Armstrong, C. (2005). Defining information literacy for U.K. Library and Information Update, 4(1-2), 22-25.

Bai, L., \& Hudson, P. (2010). Examining research productivity of Chinese TEFL academics across departments and institutes. International Journal for Researcher Development, 1 (3), 191-205. https://doi.org/10.1108/1759751X201100017

Barjak, F. (2006). Research productivity in the Internet era. Scientometrics, 68(3), 343-360.

Baron, R.M., \& Kenny, D.A. (1986). The moderator-mediator variable distinction in social psycho logical research: Conceptual, strategic and statistical considerations. Journal of Personality and Social Psychology, 51(6), 1173-1182. https://doi.org/10.1037/00223514.51.6.1173

Bartletti, J.E., Kotrlik, J.W., \& Higgins, C.C. (2001). Organisational research: Determining appropriate sample size in survey research. Information Technology, Learning and Performance Journal, 19(1), 43-50. 
Bawden, D., \& Brophy, J. (2005). Is Google enough? Comparison of an Internet search engine with academic library resources. Aslib Proceedings: New Information Perspectives, 57(6), 498-512.

Behrens, S.J. (1994). A conceptual analysis and historical overview of information literacy. College and Research Libraries, 55(4), 309-322.

Bentley, P. (2012) Gender differences and factors affecting publication productivity among Australian university academics. Journal of Sociology, 48(1), 85-103.

Bertrand, M., Goldin, C., \&. Katz, L. (2010). Dynamics of the gender gap for young professionals in the financial and corporate sectors. American Economic Journal: Applied Economics, 2(3), 228-255.

Bhukuvhani, C., Chiparausha, B., \& Zuvalinyenga, D. (2012). Effects of electronic information resources skills training for lecturers on pedagogical practices and research productivity. International Journal of Education and Development using Information and Communication Technology (IJEDICT), 8(1), 16-28.

Blackburn, T., Bieber, J., Lawrence, J., \& Trautvetter, L. (1991). Faculty at work: Focus on research, scholarship and service. Research in Higher Education, 32(4), 381-388.

Bland, C.J., Center B.A, Finstad, D.A, Risbey, K.R., \& Staples, J.G (2005). Theoretical, practical, predictive model of faculty and department research productivity. Academic Medicine, 80(3), 225-237.

Bozeman, B., \& Corley, E. (2004). Scientists' collaboration strategies: Implications for scientific and technical human capital. Research Policy, 33(4), 599-616.

Bruce, C. (1995). Information Literacy: A framework for higher education. The Australian Library Journal, 44(3), 158-170.

Carnagie Foundation for the Advancement of Teaching. (1991). Change: Trendlines: The payoff for publication leaders: By the Carnegie Foundation for the Advancement of Teaching. Change: The Magazine of Higher Learning, 23(2), 27-30. doi:10.1080/00091383.1991.9937676

Carayol, N., \& Matt, M. (2006). Individual and collective determinants of academic scientists' productivity. Information Economics and Policy, 18(1), 55-72.

Ceci, S.J., \& Williams, W.M. (2010). Sex differences in math-intensive fields. Current Directions in Psychological Sciences, 19(5), 275-279.

Chen, Y., Gupta, A., \& Hoshower, L. (2006). Factors that motivate business faculty to conduct research: An expectancy theory analysis. Journal of Education for Business, 81(4), 179189.

Cowden, M., Mclaren K., Alison P., \& Sawer, M. (2012). Women's advancement in Australian political science: Workshop report. Canberra: Australian Political Science Association.

Creswell, J. (2014). Qualitative, quantitative and mixed methods approaches $\left(4^{\text {th }} \mathrm{ed}\right.$.). Thousand Oaks, CA: SAGE Publications Inc.

Creswell, J.W. (2008). Educational research: Planning, conducting, and evaluating quantitative and qualitative research. Upper Saddle River, N.J: Pearson/Merrill Prentice Hall.

D’Amico, R., Vermigli, P., \& Canetto, S.S. (2011). Publication productivity and career advancement by female and male psychology faculty: The case of Italy. Journal of Diversity in Higher Education, 4(3), 175-184. https://doi.org/10.1037/a0022570

Dakik, H.A., Kaidbey, H., \& Sabra, R. (2006). Research productivity of the medical faculty at the American University of Beirut Postgrad. Postgraduate Medical Journal, 82(969) 462-464. 
Diamond, A.M. (1985). The money value of citations to single-authored and multipleauthored articles. Scientometrics, 8(5-6), 315-320.

Dozier, D., Sha, B.L., \& Okura, M. (2007). How much does my baby cost? An analysis of gender differences in income, career interruption, and child bearing. Public Relations Journal, 1(1), 1-16.

Ebadi, A., \& Schiffauerova, A. (2016). Gender difference in research output: Funding and collaboration. International Scholarly and Scientific Research \& Innovation, 10(4), 1313-1318.

Egunjobi, R.A. (2001). Academic status for librarians in colleges of education: The unsettled issues. In Quadri, R.F., \& Gbadamosi B.O. (Eds.), Issues in library and information services (pp. 59-69). Ibadan: Emola-Joy Communication Inc.

E-Journals: Their use, value and impact: Final report. (2011). London: Research Information Network. Retrieved from http://rin.ac.uk/system/files/attachments/Ejournals_part_II_for_screen_0.pdf

Ergart, R. (2002). An explanation of the importance of electronic resources in undergraduate research. Feliciter, 48(4), 181-185.

Erickson, K., \& Prügl, E. (2010). Women and academic organizations in international studies. In R.A. Denmark (Ed.), Oxford research encyclopedia of international studies. Storrs, CT: International Studies Association. Retrieved from http://www.isacompendium.com

Federal Republic of Nigeria. (2000). Scheme of service for use in the civil service of the Federation of Nigeria. Abuja: Office of the Head of Service of the Federation.

Fehr, E., \& Schmidt, K. (2000). A theory of fairness, competition, and cooperation. Quarterly Journal of Economics, 114(3), 817-868.

Feyera, T., Atelaw, H., Hassen, N. A., \& Fufa, G. (2017). Publication productivity of academics in Jigjiga University, Ethiopia. Educational Research and Reviews, 12(9), 559-568.

Finkelstein, M., Seal, R., \& Schuster, J. (1998). The new academic generation: A profession in transformation. Baltimore, MD: Johns Hopkins University Press.

Founad, R. (2000). Improving information literacy at Idaho State University (A proposal submitted to the University Library Committee).

Frandsen, T.F., Jacobsen, R.H., Wallien, J.A., Brixena, K., \& Ousagere, J. (2015). Gender differenced in scientific performance: A bibliometric matching analysis of Danish health sciences graduates. Journal of Informetrics, 9(4), 1007-1017.

Gibbs, P., \& Locke, B. (1989). Tenure and promotion in accredited graduate social work program. Journal of Social Work Education, 25(2), 126-133.

Glover, J. (2002). Women and scientific employment: Current perspectives from the UK. Science Studies, 15(1), 29-45.

Hedjazi, Y., \& Behravan, J. (2011). Study of factors influencing research productivity of agriculture faculty members in Iran. Higher Education, 62(5), 635-647. https://doi.org/10.1007/s10734-011-9410-6

Hesli, V.L., \& Lee, J.M. (2011). Faculty research productivity: Why do some of our colleagues publish more than others? Political Science \& Politics, 44(2), 393-408.

Jacobson, R.L. (1992, April 15). Colleges face new pressure to increase faculty productivity. Chronicle of Higher Education, 38(32), A1, 16-18.

Jonkers, K., \& Tijssen, R. (2008). Chinese researchers returning home: Impact of international mobility on research collaboration and scientific productivity. Scientometrics, $77(2)$, 309-317. 
Jungbauer-Gans, M., \& Gross, C. (2013). Determinants of success in university careers: Findings from the German academic labor market/erfolgsfaktoren in der wissenschaft ergebnisseaus einer habilitiertenbefragung an deutschen universitäten. Zeitschrift für Soziologie, 42(1), 74-92.

Kinengyere, A.A. (2007). The effect of information literacy on the utilization of electronic resources in selected academic research institutions in Uganda. The Electronic Library, 25(3), 328-341.

Koganuramah, M.M., Angadi, M., \& Kademani, B.S. (2002). Bibliometric dimension of innovation communication productivity of TATA institute of social sciences. Malaysian Journal of Library and Information Science, 7(1), 69-76.

Kostoff, R. (1995). Federal research impact assessment: Axioms, approaches applications, Scientometrics, 34(2), 163-206.

Kotrlik, J, Bartlett, J, Higgins, C., \& Williams, H. (2002). Factors associated with research productivity of agricultural educational faculty. Journal of Agricultural Education, 43(3), 1-10.

Kumar, H.A., \& Dora, M. (2012). Research productivity in a management institute: An analysis of research performance of Indian Institute of Management Ahmedabad during 1999-2010. DESIDOC Journal of Library \& Information Technology, 32(4), 365-372

Retrieved from

https://www.researchgate.net/publication/259659414_research_productivity_in_a_man agement_institute_an_analysis_of_research_performance_of_indian_institute_of_mana gement_ahmedabad_during_1999_to_2010

Kwiek, M. (2018). High research productivity in vertically undifferentiated higher education system: Who are the top performers? Scientometrics, 115(1), 415-462. https://doi.org/10.1007/s11192-018-2644-7

Kyvik, S., \& Aksnes, D.W. (2015). Explaining the increase in publication productivity among academic staff: A generational perspective. Journal Studies in Higher Education, 40, 1438-1453. https://doi.org/10.1080/03075079.2015.1060711

Larivière, V., Vignola-Gagné, E., Villeneuve, C., Gélinas, P., \& Gingras, Y. (2011). Sex differences in research funding, productivity and impact: an analysis of Québec university professors. Scientometrics, 87(3), 483-498.

Leahey, E. (2006). Research specialization as a missing link. Gender \& Society, 20(6), $754-$ 780. https://doi.org/10.1177/0891243206293030

Lee, S., \& Bozeman, B. (2005). The impact of research collaboration on scientific productivity. Social Studies of Science, 35(5), 673-702. https://doi.org/10.1177/0306312705052359

Levin, S., \& Stephan, P. (1991). Research productivity over the life cycle: Evidence for academic scientific. The American Economic Review, 81(1), 114-132.

Lin, Y. (2001). Collaborative efforts in cross-country studies on information sharing infrastructure between China and USA: Introducing an international cooperative research method. In 67th IFLA Council and General Conference, August 16-25, 2001. Retrieved from http://origin-archive.ifla.org/IV/ifla67/papers/122-165e.pdf

Lone, F.A., \& Hussain, M. (2017). Gender variations in research productivity: Insights from scholarly research. Library Philosophy and Practice (e-journal), 1608. Retrieved from https://digitalcommons.unl.edu/libphilprac/1608/

Lutter, M., \& Schröder, M. (2016). Who becomes a tenured professor, and why? Panel data evidence from German sociology, 1980-2013. Research Policy, 45(5), 999-1013. 
Lyytinen, K., Baskerville, R., Livari, J., \& Te'eni, D. (2007). Why the old world cannot publish? Overcoming challenges in publishing high-impact IS research. European Journal of Information Systems, 16(4), 317-326.

Madu, E.C., \& Dike, V.W. (2012). An assessment of the relationship be tween information literacy competencies and academic: Productivity amongst staff in Nigerian universities in north central geographical zone. Journal of Emerging Trends in Computing and Information Science, 3(2), 179-185.

Manda, P., \& Nawe, J. (2008). The impact of electronic information resource use on research output: Experiences from Universities in Tanzania. University of Dar es Salaam Library Journal, 10(1\&2), 92-106.

Mason, J. (2011). Facet methodology: The case for an inventive research orientation. Methodological Innovations Online, 6(3), 75-92.

Mathews, T.J., \& Hamilton, B. (2009). Delayed childbearing: More women are having their first child later in life. NCHS Data Brief, 21. Retrieved from https://www.cdc.gov/nchs/data/databriefs/db21.pdf

Mauleon, E., \& Bordons, M. (2010). Male and female involvement in patenting activity in Spain. Scientometrics, 83, 605-621.

Nwosu, O.C., Obiamalu, A.R., \& Udem, O.K. (2015). Relationship between information literacy skills and research output of academic staff in Nnamdi Azikiwe University Awka, Nigeria. Journal of Applied Information Science and Technology, 8(1), 88-107.

Obibuaku, L. (2005). Nigeria's top 20 research universities emerge: A comment. Retrieved from http://www.gamji.com

Ochai, A. (1998). Publication output of librarians: The search for alternative justification. African Journal of Library and Information Science, 82(2), 89-96.

Okendo, O.E. (2018). Constraints of research productivity in universities in Tanzania: A case of Mwenge Catholic University, Tanzania. International Journal of Education and Research, 6(3), 201-210.

Okiki, O.C., \& Mabawonku, I. (2013). Impact of information literacy skills on academic staff research productivity in Nigerian federal universities. Information and Knowledge Management 3(2). Retrieved from http://works.bepress.com/chrisokiki/10

Okiki, O.C. (2013). Information literacy skills as factors influencing research productivity of academic staff in Nigerian federal universities (Unpublished PhD thesis). Department of Library, Archival and Information Studies, University of Ibadan, Nigeria.

Omolewa, M. (2008). Most universities are in deplorable state. The Nigeria Educational Time, 20(July-August), 16-18.

Osunade, O., Phillips, O.F., \& Ojo, O. (2007). Limitation of knowledge sharing in academia: A case from Nigeria. Knowledge Management for Development Journal, 3(1), 26-34.

Pau, A., Omar, H., Khan, S., Jassim, A., Seow, L.L., \& Toh, C.G. (2017). Factors associated with faculty participation in research activities in dental schools. Singapore Dental Journal, 38, 45-54. https://doi.org/-10.1016/j.sdj.2017.08.001

Popoola, S.O. (2008). The use of information sources and services and its effect on the research output of social scientists in Nigerian universities. Library Philosophy and Practice, 183(4), 1-10.

Preffer, J., \& Langton, N. (1993). The effect of wage dispersion on satisfaction, productivity, and working collaboratively: Evidence from college and university faculty. Administrative Science Quarterly, 382-382.

Print, M., \& Hattie, J. (1997). Measuring quality in universities: An approach to weighting research activity. Higher Education, 33(4), 453-469. 
Pudovkin, A., Kretschmer, H., Stegmann, J., \& Garfield, E. (2012). Research evaluation. Part I: Productivity and citedness of a German medical research institution. Scientometrics, 93, 3-16. https://doi.org/10.1007/s11192-012-0659-z

Puuska, H.M. (2010). Effects of scholar's gender and professional position on publishing productivity in different publication types: Analysis of a Finnish university. Scientometrics, 82(2), 419-437.

Qung, H., \& Grandom, G. (2000). Is faculty research productivity: Influential factors and implications. Information Resources Management Journal, 13(2), 15-26.

Ramsden, P. (1994). Describing and explaining research productivity. Higher Education, 28(2), 207-226.

Rowlands, I., \& Olivieri, R. (2007). Research productivity and the journals system: A study of immunology and microbiology authors. Research Evaluation, 16(1), 23-34. https://doi.org/10.3152/095820207X196759

Sabharwal, M. (2013). Comparing research productivity across disciplines and career stages. Journal of Comparative Policy Analysis: Research and Practice, 15(2), 141-163.

Saimroh, S. (2017). Factors affecting the research productivity in government institutions. Analisa Journal of Social Science and Religion, 2(1), 139-159. Retrieved from https://www.neliti.com/publications/89793/factors-affecting-the-research-productivityin-government-institutions

Sarkese, M.R., \& Henehan, M.T. (2010). International studies as a discipline and women's status therein. In R.A. Denmark (Ed.), Oxford research encyclopedia of international studies. Storrs, CT: International Studies Association. Retrieved from http://www.isacompendium.com

Sayed, Y. (1998). The segregated information highway: Information literacy in higher education. Cape Town, South Africa: UCT Press.

Shin, J.C., \& Cummings, W.K. (2010). Multilevel analysis of academic publishing across disciplines: Research preference, collaboration, and time on research. Scientometrics 85(2), 581-594.

Sotudeh, I., \& Khoshian, N. (2013). Gender differences in science: The case of scientific productivity in nano science \& technology during 2005-2007. Scientometrics, 98(1) 457-472. https://doi.org/10.1007/s11192-013-1031-7

Stack, S. (2004). Gender, children and research productivity. Research in Higher Education, 45(8), 891-920.

Sulo, T., Kendagor R., Kosgei D., Tuitoek D., \& Chelangat, S. (2012). Factors affecting research productivity in public universities of Kenya: The case of Moi University. Journal of Emerging Trends in Economics and Management Sciences, 3(5), 475-484.

Tasli, L., Kacar, N., \& Aydemir, E.H. (2012). Scientific productivity of OECD countries in dermatology journals within the last 10-year period. International Journal of Dermatology, 51(6), 665-671.

Teodorescu, D. (2000). Correlates of faculty publication productivity: A cross-national analysis. Higher Education, 39(2), 201-222.

Tornquist, K.M., \& Kallsen, L.A. (1992). Out of the ivory tower: An analysis of the institutional characteristics of universities from which firms acquire scientific result.

Paper presented at the Annual Meeting of the Association for the Study of Higher Education, Minneapolis, 29 October-3 November, 1992. Retrieved from https://files.eric.ed.gov/fulltext/ED352913.pdf

Turnage, J. (1990). The challenge of the new workplace technology for psychology. American Psychologist, 45(3), 171-178. 
Usang, B., Basil, A., Lucy, U., \& Udey, F.U. (2007). Academic staff research productivity: A study of universities in South-South Zone of Nigeria. Educational Research and Reviews, 2(5), 103-108.

Ureigho, R.J., Oroke, G.U., \& Ekruyota, G.O. (2006). The impact of Internet usage: A case study of Delta State (Nigeria) tertiary institutions. Scientific Research and Essay, 1(2), 54-56.

Wadesango, N. (2014). Publish or perish: Impediments to research output and publication. International Journal of Educational Sciences, 6(1), 57-63.

Whiston, T.G., \& Geiger, R.L. (Eds.). (1992). Research and higher education: The United Kingdom and the United States. Buckingham, UK: Open University Press.

White, H.D., Boell, S.K., Yu, H., Davis, M., Wilson, C.S., \& Cole, F.T.H. (2009).

Libcitations: A measure for comparative assessment of book publications in the humanities and social sciences. Journal of the American Society for Information Science and Technology, 60(6), 1083-1096.

Williams, A. (2000). Research productivity of nursing faculty (Unpublished Doctoral Dissertation). University of Louisville.

Williams, A. (2003). A mediated hierarchical regression analysis of factors related to research productivity of human resource education and workforce development post-secondary faculty (Doctoral dissertation). Retrieved from Lousiana State University (LSU) Digital Commons. (LSU Doctoral Dissertations, 1765; https://digitalcommons.lsu.edu/gradschool_dissertations/1765/87)

Williams, W.M., \& Ceci, S.J. (2012). When scientists choose motherhood. American Scientist, 100, 138-145.

Williams, H., Bartlett, J., Kotrlik, J., \& Higgins, C. (2002). An analysis of factors associated with research productivity of human resource development faculty. In Academy of Human Resource Development Conference Proceedings 2002 (paper 42-4). Baton Rouge, LA: The Academy. Retrieved from https://eric.ed.gov/?id=ED474240

Wills, D., Ridley, G., \& Mitev, H. (2013). Research productivity of accounting academics in changing and challenging times. Journal of Accounting \& Organizational Change, 9(1), 4-25.

Wilson, L.A. (2001). Information literacy: Fluency across and beyond the university. In B.L. Dewey (Ed.), Library user education: Powerful learning, powerful partnership (pp. 117). Lanham, MD: Scarecrow Press, Inc.

\section{APPENDIX \\ INFORMATION LITERACY SKILLS, SOCIO-ECONOMIC FACTORS AND RESEARCH PRODUCTIVITY (ILSSERP) QUESTIONNAIRE FOR ACADEMIC STAFF}

\section{SECTION A: SOCIO-ECONOMIC FACTORS}

1. Name of Research Institute

2. Department/Unit

3. Academic Status: Research Scientist [ ] Senior Scientist [ ] Principal Scientist [ ] Asst Director [ ] Deputy Director [ ] Others (pls specify):

4. Gender: Male [ ] Female [ ]

5. Age: 
6. Highest academic qualification

PhD [ ] M.Phil [ ] Master [ ] PGD [ ] Bachelor Degree [ ]

7. How long have you been working as an academic staff in this Institute

8. Marital Status: Married [ ] Single [ ] Divorced [ ] Separated [ ] Widowed [ ]

9. Religion:

10. Monthly Salary:

11. Nature of Employment: Fulltime [ ] Contract [ ] Part-time/Adjunct [ ] Sabbatical [ ]

12 . What is size of your nucleus family?

\section{SECTION B: INFORMATION LITERACY SKILLS FOR RESEARCH PRODUCTIVITY SCALE (ILSRP)}

This scale has been prepared to determine your level of information literacy skills

Here the notations shall be referred to as $5=$ Always True, $4=$ Often True, $3=$ Usually True, 2 = occasionally true, $\mathbf{1}=$ Not True. Please mark the most suitable choice for you. NOTEs: $\mathbf{A}=$ Defining the need for information; $\mathbf{B}=$ Initiating the search strategy; $\mathbf{C}=$ Locating and accessing the resources; $\mathbf{D}=$ Assessing and comprehending information; $\mathbf{E}=$ Interpreting, synthesizing, and using information; $\mathbf{F}$ $=$ Communicating Information; and $\mathbf{G}=$ Evaluating the product and process.

\begin{tabular}{|c|c|c|c|c|c|c|}
\hline Item & As an academic staff I feel confident and competent that: & 1 & 2 & 3 & 4 & 5 \\
\hline$\grave{\mathbf{A} 1}$ & I can define the information that I need & & & & & \\
\hline B2 & I can identify a variety of potential sources of information & & & & & \\
\hline B3 & I can limit search strategies by subject, language and date & & & & & \\
\hline B4 & I can initiate search strategies by using keywords and Boolean logic & & & & & \\
\hline $\mathbf{C 5}$ & I can decide where and how to find the information I need & & & & & \\
\hline C6 & I can use different kinds of print sources (such as books, periodicals) & & & & & \\
\hline $\mathbf{C 7}$ & I can use electronic information sources & & & & & \\
\hline C8 & I can locate information sources in the library & & & & & \\
\hline C9 & I can use library catalogue & & & & & \\
\hline C10 & I can interpret information on the library catalogue & & & & & \\
\hline C11 & I can locate resources in the library using the library catalogue & & & & & \\
\hline $\mathbf{C 1 2}$ & I can use internet search tools (such as search engines, directories, etc. & & & & & \\
\hline C13 & I can use different kinds (types) of libraries & & & & & \\
\hline C14 & $\begin{array}{l}\text { I can use different kinds of library catalogues (i.e. card catalogues, } \\
\text { online catalogues) }\end{array}$ & & & & & \\
\hline C15 & I can Use/search indexes and electronic databases & & & & & \\
\hline D16 & I can use many resources at the same time to make a research & & & & & \\
\hline D17 & I can differentiate between fact and opinion & & & & & \\
\hline D18 & I can recognize errors in logic & & & & & \\
\hline D19 & I can classify the information & & & & & \\
\hline D20 & I can recognize interrelationships among concepts & & & & & \\
\hline D21 & $\begin{array}{l}\text { I can determine the authoritativeness, currentness and reliability of the } \\
\text { information sources }\end{array}$ & & & & & \\
\hline D22 & I can evaluate information critically & & & & & \\
\hline $\mathbf{D 2 3}$ & I can select information most appropriate to the information need & & & & & \\
\hline D24 & I can identify points of agreement and disagreement among sources & & & & & \\
\hline D25 & I can evaluate www sources & & & & & \\
\hline
\end{tabular}




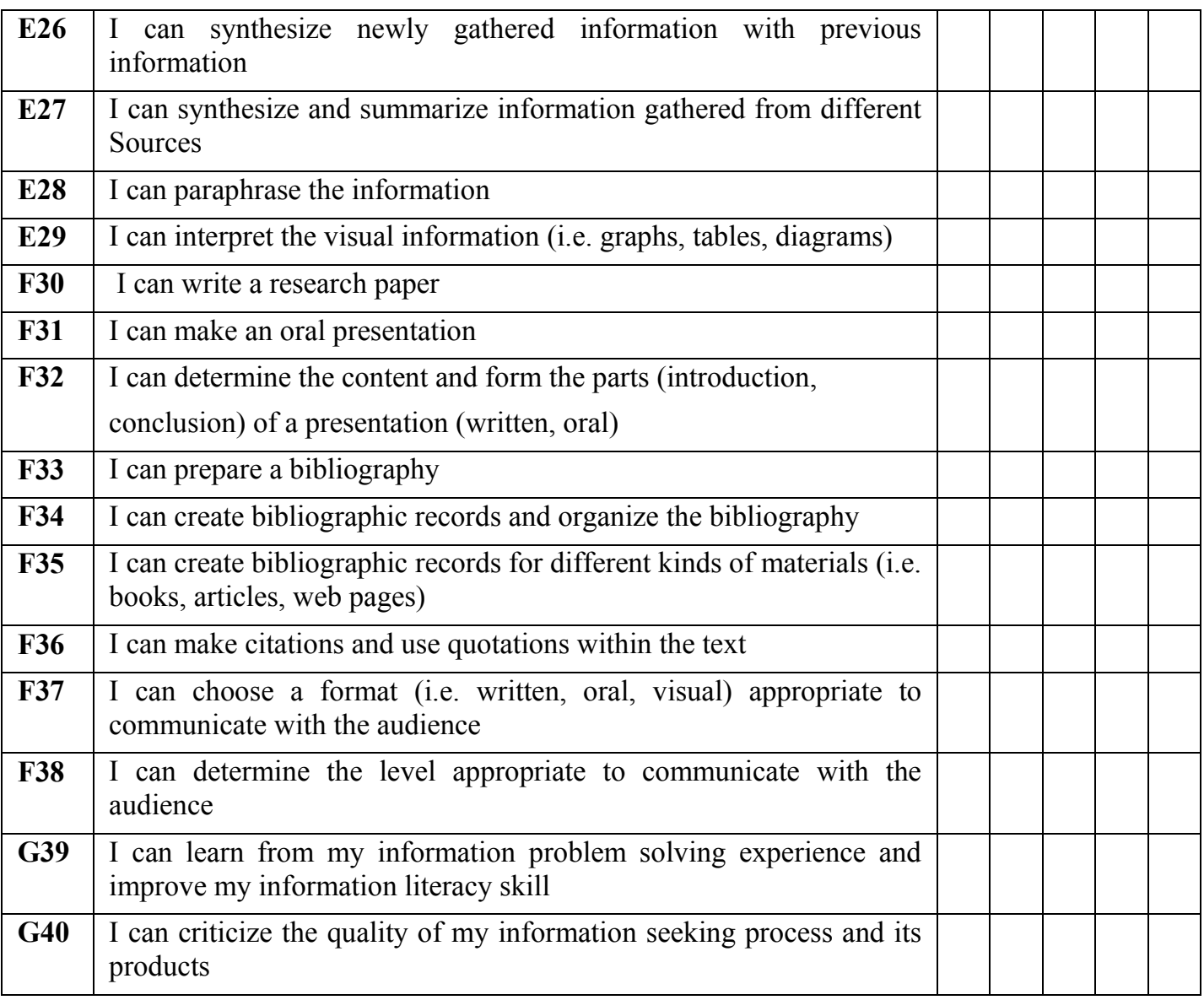

SECTION C: RESEARCH PRODUCTIVITY

Kindly indicate the pattern of your research publications within the period of 6 years (20092014)

\begin{tabular}{|l|l|l|l|}
\hline Research Productivity & $\begin{array}{l}\text { Local } \\
\text { Publications }\end{array}$ & $\begin{array}{l}\text { International } \\
\text { Publications }\end{array}$ & Total \\
\hline Text Books & & & \\
\hline Chapters in books & & & \\
\hline Co-authored textbooks & & & \\
\hline Articles in journals & & & \\
\hline Thesis/dissertation & & & \\
\hline Patents & & & \\
\hline Conference Proceedings & & & \\
\hline Technical Reports & & & \\
\hline Occasional papers & & & \\
\hline Monographs & & & \\
\hline Scientific peer-reviewed bulletin & & & \\
\hline
\end{tabular}

